\title{
The Relevance of Reading Materials Presentation in Indonesian Textbook for Grade Vii Junior High School: Learner Characteristics Review
}

\author{
Laili Etika Rahmawati ${ }^{*}$, Dwi Kurniawati, Hari Kusmanto, Yakub Nasucha, Abdul Ngalim \\ Department of Indonesian Language and Literature Education, Faculty of Teacher Training and Education, Universitas \\ Muhammadiyah Surakarta, Surakarta 57102, Indonesia
}

Received June 8, 2020; Revised November 10, 2020; Accepted November 29, 2020

\section{Cite This Paper in the following Citation Styles}

(a): [1] Laili Etika Rahmawati, Dwi Kurniawati, Hari Kusmanto, Yakub Nasucha, Abdul Ngalim , "The Relevance of Reading Materials Presentation in Indonesian Textbook for Grade Vii Junior High School: Learner Characteristics Review," Universal Journal of Educational Research, Vol. 8, No. 12, pp. 7047 - 7053, 2020. DOI: 10.13189/ujer.2020.081272.

(b): Laili Etika Rahmawati, Dwi Kurniawati, Hari Kusmanto, Yakub Nasucha, Abdul Ngalim (2020). The Relevance of Reading Materials Presentation in Indonesian Textbook for Grade Vii Junior High School: Learner Characteristics Review. Universal Journal of Educational Research, 8(12), 7047 - 7053. DOI: 10.13189/ujer.2020.081272.

Copyright $@ 2020$ by authors, all rights reserved. Authors agree that this article remains permanently open access under the terms of the Creative Commons Attribution License 4.0 International License

\begin{abstract}
This study aims to: (1) identify the presentation of reading material in grade VII Indonesian textbook and (2) describe the relevance of the presentation of reading material in grade VII Indonesian textbook based on the characteristics of the learners. The research approach used is descriptive qualitative. The data used in this study is the presentation of description text in the seventh-grade Indonesian textbook published by Erlangga. The data source of this research was a document, namely Indonesian grade VII Indonesian textbook. The data collection technique of this study used the documentation and listening methods and continued with the note-taking technique. Analysis of the data of this study used the content analysis method. The validity test of the data in this study used the triangulation theory. The results showed that from the 60 reading material data (1) 11 data are not relevant to students because of characteristics relating to initial abilities, such as intellectual ability, thinking ability, and movement ability. (2) 46 data are not relevant to students because of characteristics relating to social-cultural background and status. (3) 3 data are not relevant to students because of characteristics relating to personality differences, such as nature, attitudes, feelings, interests, and so on. This shows the need for material adjustments to the characteristics of students' abilities, social background characteristics, and personality
\end{abstract}

characteristics. The preparation of textbooks in the future should pay attention to intellectual, sociological, and psychological characteristics of students.

Keywords Reading Material, Textbook, High School, Learner Characteristics, Intellectual Ability

\section{Introduction}

Presentation of material in textbooks must be relevant to the characteristics of the learner. It can help the learning process and objectives. However, in reality, it was found that the presentation of material in textbooks was lacking and not relevant to the characteristics of the learners.

Textbooks, as one of the supporting instruments of learning, are still considered important and determine the success of the learning process. The success or failure of the learning process can be partially determined by the textbook selected and used as a learning instrument. However, it is found that not all textbooks chosen by the teacher as a learning resource optimally support learning achievement.

The teacher has an important role in choosing the textbook to be used as a learning resource. The teacher's 
accuracy in choosing textbooks is one of the initial successes of the learning process. Textbooks such as guides and Learning Implementation Plans to guide the learning process in one semester.

Educators must pay attention to several aspects that are used as consideration for the selection of textbooks as a source of learning. One important aspect is the material presented in the textbook that should have relevance to the characteristics of the learner. Materials with a high level of relevance facilitate students in understanding the material presented in textbooks. On the contrary, if the material presented in the textbook is lacking and even irrelevant to the characteristics of the learner, the learning process will find it difficult to reach the goal.

Reading activity is mental activity to understand what the other party tells through writing [18]. If listening activities require knowledge of the sound system of the language concerned, reading activities require knowledge of the writing system, especially concerning letters and spelling. Students' reading ability will affect the ability to understand the reading material presented in textbooks [15]. Thus, reading is not just an activity that just looks at a collection of words, but there is an activity of the process of transfer of knowledge and processing of knowledge based on the materials presented through the material in textbooks.

\section{Literature Review}

Textbooks are one of the teaching materials used by teachers and serve as learning resources and media that support the achievement of competencies that are the objectives of learning. Textbooks are student and teacher handbooks, accompanied by supporting learning materials, deliberately compiled by experts in education and languages to be delivered to students [13]. A similar idea was stated by Piper, Simmons Zuilkowski, Dubeck, Jepkemei\& King; Surma., Vanhoyweghen., Camp \&Kirschner that textbooks in learning include having a central role in achieving learning objectives [33, 34].

Tarigan states that textbooks are the same as learning books. Textbooks are basically part of a curriculum that contains subject matter to achieve educational goals [27]. This is in accordance with what Kim stated, Kom \& King textbooks are a means of interpreting content and curriculum methods to efficiently achieve the curriculum objectives that have been prepared. Thus, textbooks are more practical to use in learning because they have been adapted to the curriculum [35].

Communication between educators and students in the world of education must always be well established in order to achieve educational goals. The teacher will help students in building students' abilities, namely in the cognitive, affective, and psychomotor aspects. It certainly requires an effective learning tool. Suryaman suggests that one of the most important tools is the provision of textbooks or subject books as a good and correct reference for students. The level of importance is because textbooks are one of the significant tools in supporting the learning process. The absence of textbooks will make learning process heads to the unclear direction, and thus the learning objectives are also difficult to achieve [36].

Textbooks have a big role in the learning process, which is as one of the supports in improving the quality of learning. This is consistent with what stated by Piper., Simmons Zuilkowski., Dubeck., Jepkemei\& King, that textbooks are important elements in improving learning that should not be left behind in the implementation of learning [33]. Textbooks are a mean of knowledge; thus, textbooks are very important in learning practice [34].

Based on the opinions expressed by experts, it shows that textbooks are an important element in learning. A good textbook will have a powerful effect on increasing the competency of students. The effective power of each textbook is different; the greater the increase in student competency, the more quality the textbook has [37].

Reading is a process of understanding that combines information that is known with information that is unknown [21, 31]. In line with this opinion, Khotimah, Dadan \& Dadang states that reading is an oral activity or only in the heart by looking at the writing on a text [12]. Furthermore, Astuti suggested that reading is an active process of thought through the eyes to capture messages or meanings in texts [5].

The meaning of reading does not lie in a text but is in the reader's mind. Samniah argues that reading is a process of understanding the implicit in what is written, the meaning contained in written words [22]. In line with this opinion, reading is an activity or cognitive process that seeks to find various information contained in writing [8]. Meanwhile, Tarigan argues that reading is a process that is carried out and used by readers to obtain messages, which are intended to be conveyed by the writer through the media of words / written language [27].

Without reading, student educational process might feel hollow. This can be understood because reading is the initial process of knowledge and knowledge transfer. Reading written texts at this time is still relevant to improve students' understanding. This is consistent with what Valentini, Ricketts, Pye \& Houston-price stated, that understanding words or material in textbooks is easier to understand through reading written texts [29].

Students are one of the human components that occupy a central position in the education process. In a pedagogical perspective, learners are interpreted as a kind of creature "homo educandum", a creature that desires education [10]. A similar opinion was conveyed by Budiningsih; students are humans who have a history, creatures with unique characteristics (individuality) [6].

Characteristics of students are the uniqueness that is 
owned by each student in the learning process [19]. In line with this opinion, Sari states that character of students is character, nature, or things that are very basic that exists in a student in developing abilities through the educational process both related to God, self, fellow human beings, and environment [23]. Nurbaeti states that the character of students is the aspects or individual qualities owned by the students [17].

The definition of characteristics of students proposed by Nurbaeti refers to what characters are inherent in the students themselves. Nurhamidah states the characteristics of students, among others, are (1) physical development, (2) socio-emotional, (3) moral, (4) cultural, and (5) intellectual [19]. A similar opinion was conveyed by Sitanggang\& Abdul), characteristics of students that need attention are (1) characteristics relating to initial abilities, such as intellectual abilities, thinking abilities, and movement abilities, (2) characteristics related to background and socio-cultural status, and (3) characteristics relating to personality differences, such as nature, attitudes, feelings, interests and so on [25].

After the teacher understands and explores the characteristics of students related to their interests, talents, and needs, the teacher needs to provide teaching materials in accordance with the characteristics of the students. The success of achieving learning goals is mainly determined by the teaching and learning process and the development of teaching materials used by teachers [30]. The selection of types of teaching materials is determined based on the level of difficulty and depth of the material, the characteristics of the subject matter, the complexity in the selection of learning strategies, the character of learners, the condition of learning facilities and infrastructure by paying attention to the needs of students $[4,11]$. Therefore, interesting teaching materials are needed so that students are more interested and motivated.

The main problem examined in this study is the relevance of the presentation of reading texts in Indonesian textbooks based on a review of learner characteristics. The purpose of this study is to describe the relevance of the presentation of reading texts in Indonesian textbooks based on a review of learner characteristics.

\section{Methods}

The research approach is in the form of qualitative [28, $32,38]$. The qualitative descriptive approach in this study aims to produce description data, namely the description of the relevance of the presentation of reading material in VII grade Indonesian textbooks published by the publisher Erlangga. The research data is reading material in Indonesian textbooks. The data source of this research is VII grade Indonesian textbooks. The data collection of this study used the document and observation method and continued with the note-taking technique. The document referred to is the Indonesian textbook which is used as the object of research. The method of observation is done by reading carefully and thoroughly to find the relevance of reading material based on learner characteristics. After reading and data obtained, the next step is to record data on the data card. Analysis of the data of this study uses the content analysis method. The content analysis method is carried out by analyzing the presence of Indonesian textbook reading material that is associated with the characteristics of learners in a particular school. The validity test of the data in this study uses the triangulation theory.

\section{Results and Discussion}

The results and discussion of this research will be focused more on the presentation of reading material and the relevance of reading material in textbooks for grade VII junior high schools based on learner characteristics. This needs to be done as a form of criticism and improvement in the presentation of material in textbooks. The results of this study aim to provide input for improvement so that in the future, textbook writers pay more attention to aspects of the presentation of material based on learner characteristics.

\subsection{Presentation of Reading Materials in Indonesian Textbooks (Data 1, Data 2, Data 3)}

Presentation of material in textbooks should be presented and adjusted to the development of learning characteristics of students. This means that the material presented should not be too easy or too difficult for students to understand. As for what is meant by the development of learning characteristics of students, it is seen from several aspects, which include (1) physical development, (2) socio-emotional, (3) moral, (4) cultural, and (5) intellectual.

In addition, the presentation of material in textbooks must also be able to motivate students to enjoy reading. The positive effect of reading instruction felt by Chinese students mainly comes from strategies and metacognitive-based instructions, teacher support, and the nature of the task [14]. The opinion expressed by Lau \& Xiao-bo shows the teacher's role in increasing students' interest and reading ability in the context of learning. Command and motivation have a strategic and central role in increasing students' interest and reading ability. If the reading power of students is good, good literacy skills will be achieved.

However, unattractive text presentation will make students lazy to read. Furthermore, the students experienced a decrease and their learning power [20]. This is in accordance with what Arua \& Comfort stated that the majority of students are fonder of reading academic and recreational material. Recreational texts are texts that are 
identical with things that delight students [3].

Data 1: Presentation of reading material in Data 1 is an implementation of Basic Competence 3.1 (KompetensiDasar/KD, a standard of education competence in Indonesia), identifying information in the description text about the object. Slavin states that the reading quality of students is done in a gradual manner. Data 1 presents a text that tells the depiction of an object, namely coconut trees (pohon-pohonkelapa). Coconut trees are described with words related to the depiction of human limbs, such as tergerai, belahan, ramping, meliuk-liuk, dan terjulur. The words presented in the description text use the metaphorical feature that serves to describe the coconut trees. The purpose of presenting the metaphor in the description text aims to make students able to imagine the coconut trees [26].

But the problem is that students who have never seen the coconut trees depicted in Data 1 will have difficulty imagining the meaning of the text about the coconut trees. Learning that is abstract is felt to be difficult for students in understanding the material presented. Students who are familiar with the presentation of the atmosphere in the text about the coconut trees will very easily understand the material presented. The teacher thus has a role in helping to communicate the portrayal of Data 1 with the imagination of the students.

Data 2: Presentation of reading material in Data 2 is the implementation of Basic Competence (KD) 4.1, explaining the contents of the object description text. In order for students to have the ability to explain with strong arguments, motivation for students to be diligent in reading is needed because reading is an understanding process [24]. One of them is in the context of the Industrial Revolution Era 4.0 (a national development program in Indonesia), the era of computing, and the disruption of textbook education not only focusing on printed books but electronic books that can be accessed anytime and anywhere. The use of conventional textbooks is irrelevant for use in learning in the digital age in other words, obsolete. The problem of shifting conventional textbooks can be overcome by the use of textbooks or online reading material to increase students' motivation to read [7, 39].

Data description text 2 tells the story of a village that was attacked by thousands of rats. The object told in the description text is located at villages in Pracimantoro District (desa-desa Kecamatan Pracimantoro). The attacks were carried out by thousands of rats by eating food that is owned by residents in the villages of Pracimantoro District.

Data 3: The material presented in Data 3 is the Basic Competence (KD) 3.5 implementation, identifying the procedure text on how to do something and how to make it. It is called the procedure text because the material presented has characteristics in common with the procedure, which contains steps or sequences. The steps in Data 3 present the batik procedure, which is the highlighting stage. This is evident from the first sentence, which is Setelah kering, dilakukan proses pelorotan (after dried, the degradation process is carried out).

\subsection{The Relevance of Presentation of Reading Materials in Indonesian Textbooks (Data 4, Data 5, Data 6)}

Indonesian textbooks used in this study present 16 Basic Competencies (KD), but not all KDs are objects of research. Basic competencies that are the objects of this study include KD 3.1, KD 4.1, KD 3.2, KD 3.3, KD 3.4, KD 3.5, KD 3.6, KD 3.7, KD 4.7, KD 3.8, KD 4.8, KD 3.9, KD 3.11, and KD 3.12. There are several Basic Competencies based on the researchers' observations, which are less relevant to the characteristics of students in Al-Irsyad Tawangmangu Junior High School (the studied school). Following is the analysis of the relevance of the material in Indonesian textbooks for grade VII from Erlangga publisher.

Data 4: presents a description text that tells the depiction of an object, namely coconut trees. They are described with words related to the depiction of human body parts, among others: tergerai, belahan, ramping, meliuk-liuk, and terjulur. Data 4 is considered less relevant to the character of students in junior high school because it is not in accordance with the characteristics relating to initial abilities, such as intellectual ability, thinking ability, and movement ability.

Presentation of material in data 4 is considered to be less relevant to the characteristics of learning, as in the use of words that are not in accordance with the age of students. The use of words such as tergerai which refer to a woman's long hair, so long it reaches the heel. The use of belahan seems to suggest profanity (cleavage). Furthermore, the use of the word ramping and meliuk-liuk connotes as a sexy woman and dances like a singer. The presentation of material and the use of linguistic reference, both at the morphological and syntactic levels, should use words that have denotative meaning instead of connotative meaning.

Data 5: presents the text of reading material that tells about the situation in an area, namely desa-desa di Kecamatan Pracimantoro (villages in Pracimantoro District) being attacked by tens of thousands of rats; Bahkan, penduduk beberapa desa terpaksa diungsikan Karena ketakutan (in fact, residents of several villages had to be evacuated because of fear). Pracimantoro is a district in Wonogiri Regency. Text 5 is considered to be less relevant to the conditions of learner characteristics, namely, characteristics related to socio-cultural backgrounds and status. Presentation of material in the book should also pay attention to the socio-cultural background; this is an effort to avoid cultural bias [1]. This is because the characteristics of the learner of the research object are in Al-Irsyad Tawangmangu Junior High School, an area quite far from Wonogiri Regency. 
Learners reading ability in a given text is greatly influenced by the language used, background knowledge of the language used, and cultural knowledge of the objects being told. In addition, it must be understood that the reading ability of each student varies greatly; some are very good, good, and not good [16]. Students who read a text about an area in Indonesia but do not have the imagination of the subject will have difficulty understanding the reading material. This is in accordance with what Arisandi \& Kelik stated that the reading ability and linguistic pronunciation of students are influenced by the dialect background they use [2]. In addition, the presentation of illustrations, images, concepts also has the influence to increase students' interest in reading [9]. Dialect problems can be overcome by using the national language, Indonesian, provided that students have the ability to speak the Indonesian language.

Data 6: presents a text excerpt from the batik process in the highlighting stage. This is evident from the first sentence, which is setelah kering, dilakukan proses pelorotan. One of the characteristics of students that need special attention is the characteristics relating to personality differences, such as nature, attitudes, feelings, interests and so on. If identified in-depth, text excerpt six is considered irrelevant to the characteristics of learners at the junior-high-school. Specifically, the characteristics of learners at Al-Irsyad Tawangmangu Junior High School, it would be more relevant if students were presented with a text of procedures about caring for plants.

Presentation of the text in data 6 is irrelevant because the characteristics are not in accordance with the text of the procedure that presents the batik process. Al-IrsyadTawangmanguJunior High School is located in a mountainous area which has more potential in the field of animal husbandry and agriculture, as in cattle and vegetable crops, such as green mustard, cabbage, carrots, chillies, and so on. Based on the characteristics of learning in Al-IrsyadTawangmangu Junior High School, the relevant texts are those related to the field of animal husbandry and agriculture, especially cattle and vegetable farming.

\section{Conclusion}

As mentioned earlier, in the current study, it was tried to identify the presence of reading material in grade VII Indonesian textbook and describe the relevance of the presentation of reading material in grade VII Indonesian textbook based on the characteristics of the learners. This paper is focused more on the presentation of reading material and the relevance of reading material in textbooks for grade VII junior high schools based on learner characteristics. This needs to be done as a form of criticism and improvement in the presentation of material in textbooks. The results of this study aim to provide input for improvement so that in the future, textbook writers pay more attention to aspects of the presentation of material based on learner characteristics.

Based on the results and discussion presented in this study, it can be concluded that there are 60 data of presentation of reading material that are less relevant to learner characteristics. They are divided into three groups: (1) 11 data of presentation being less relevant to learner characteristics related to initial abilities (intellectual ability, thinking ability, and ability to move); (2) 46 data of presentation being less relevant to learner characteristics related to background and socio-cultural status; (3) 3 data of presentation being less relevant to learner characteristics related to personal differences (nature, attitudes, feelings, and interests). They show that improvements in the presentation of reading material in textbooks in terms of content, illustrations, and strategy of presenting the material are a necessity that must be done. Writing the material in textbooks should not only be oriented to the material but also to the characteristics of the learner. This is an effort to improve the quality of good textbooks that have the power to enhance students' understanding of the material presented.

In the continuation of this study and for future work, it is suggested to review and compare the results of this research with textbooks in other countries. Countries that are culturally very similar to this study should be selected.

\section{REFERENCES}

[1] F. R. Abdul Hussein. Investigating EFL College Teachers 'and Learners' Attitudes toward Using Authentic Reading Materials in Misan. Procedia - Social and Behavioral Sciences. 136: 330-343. 2014.http://dx.doi.org/10.1016/j.sb spro.2014.05.338

[2] V. Arisandi, K.Wachyudi. Miscue Analysis in Reading Aloud by Indonesian English Foreign Learner. Eltin Journal. 5 (1): 17-26. 2017.

[3] A. E. Arua, C. E. Arua. The Reading Behavior of Junior Secondary Students During School Holidays in Botswana. Journal of Adolescent \& Adult Literacy. 54 (8): 589-599. 2011.

[4] I. G. A. M. Aryaningsih, N. Sudiana, N. Martha. Pengembangan Bahan Ajar Membaca Sastra Indonesia dan Perangkat Penilaian Autentik Siswa Kelas VII Semester 1 SMP Negeri 8 Denpasar. E-journal Program Pascasarjana Universitas Pendidikan Ganesha. 2: 1-10. 2013.

[5] A. P. Astuti. Pengembangan Instrumen Penilaian Kompetensi Membaca pada Mata Pelajaran Bahasa Indonesia Kelas VII Berbasis Quipper School. JINop. 2 (2): 334-350. 2016.

[6] C. A. Budiningsih. Karakteristik Siswa sebagai Pijakan dalam Penelitian dan Metode Pembelajaran. Cakrawala 
Pendidikan. (1): 160-172. 2011.

[7] A. S. Chaudhry. Student Response to E-books: Study of Attitude Toward Reading Among Elementary School Children in Kuwait. The Electronic Library. 32 (4): 458-472. 2012.

[8] Dalman. Keterampilan Membaca. Jakarta: RajaGrafindo Persada. 2013.

[9] S. L. Darmawan. Promoting Students Explicit Information Skill in Reading Comprehension Through Graphic Organizers. 2 (2): 112-119. 2013.

[10] Desmita. Psikologi Perkembangan Peserta Didik. Bandung: Remaja Rosdakarya. 2017.

[11] L. Ketsitlile, M. Commeyras. Reviewing Published Information on Reading in Botswana Secondary School. Reading \& Writing. 5 (1): 1-10. 2014.

[12] A. H. Khotimah, D. Djuanda, D. Kurnia. Keterampilan Membaca Cepat dalam Menemukan Gagasan Utama. Jurnal Pena Ilmiah. 1 (1): 341-350. 2016.

[13] I. K. Bartošová, A. Plovajková, T. Podnecká. Development of Reading Literacy Based on the Work of Textbooks (Workbooks). Procedia - Social and Behavioral Sciences171: 668-679. http://dx.doi.org/10.1016/j.sbspro.2015.01.176

[14] K. L. Lau, X. B. Chen. Perception of Reading Instruction and Self-Regulated Learning: A Comparison between Chinese Students in Hong Kong and Beijing. Instructional Science. 41 (6): 1083-1101. 2013.

[15] M. Mohd, M. Nazeri. The Use of Graded Reading Materials for Children with Reading Difficulties. Procedia - Social and Behavioral Sciences. 191: 2631-2633. 2015. http://dx.doi.org/10.1016/j.sbspro.2015.04.518

[16] B. B. Ntereke, T. R. Boitumelo. Reading Competency of First-Year Undergraduate Students at University of Botswana: A Case Study”. Reading \& Writing. 8 (1): 1-11. 2017.

[17] S. N. Nurbaeti, D. W. Indarini. Hubungan Gaya Belajar dengan Keterampilan Berpikir Kritis dan Kemampuan Kognitif Siswa pada Mata Pelajaran Kimia di Kelas X SMKN 1 Bungku Tengah. e-Jurnal Mitra Sains. 3 (2): 24-33. 2015.

[18] B. Nurgiyantoro. Penilaian Pembelajaran Bahasa: Berbasis Kompetensi. Yogyakarta: BPFE. 2014.

[19] I. Nurhamidah. Problematika Kompetensi Pedagogi Guru terhadap Karakteristik Peserta Didik. Jurnal Teori dan Praksis Pembelajaran IPS. 3 (1): 27-38. 2018.

[20] F. Okebukola, T. Owolabi, B. O. Onafowokan. An Assessment of the Reading Motivation Skills of Nigerian Primary School Teachers: Implications for Language and Science Education. Reading \& Writing. 4 (1): 1-12. 2013.

[21] G. Pleisch, I. I. Karipidis, C. Brauchli, M. Röthlisberger, C. Hofstetter, P. Stämpfli,... S. Brem. Emerging neural specialization of the ventral occipitotemporal cortex to characters through phonological association learning in preschool children. NeuroImage. 189 (July): 813-831. 2019. Doi 10.1016/j.neuroimage.2019.01.046
[22] N. Samniah. Kemampuan Memahami Isi Bacaan Siswa Kelas VII MTs Swasta Labibia. Jurnal Humanika. 1 (16): 1-15. 2016.

[23] A. R. Sari, W. Budhi. Hubungan Antara Karakter Siswa, Kedisiplinan Siswa, dan Kelengkapan Sarana Prasarana Sekolah dengan Prestasi Belajar Sekolah. Compton. 4 (1): 1-12. 2017.

[24] E. Segers, L. Verhoeven. Learning and Individual Differences, Cognitive and linguistic precursors of early first and second language. Learning and Individual Differences. 7(march): 1-14. 2019. https://doi.org/10.1016/j.lindif.2019. 03.008

[25] N. Sitanggang, A. H. Saragih. Studi Karakteristik Siswa SLTA di Kota Medan. Jurnal Teknologi Pendidikan. 6 (2): 185-196. 2013.

[26] R. E. Slavin. Effective Reading Programs for Middle and High Schools: A Best-Evidence Synthesis. Reading Research Quarterly. 43 (3): 290-322. 2008.

[27] H. G. Tarigan. Membaca: Sebagai Suatu Keterampilan Berbahasa. Bandung: Angkasa. 2008.

[28] H. Tojo, A. Takagi. Trends in Qualitative Research in Three Major Language Teaching and Learning Journals, 20062015. International Journal of English Language Teaching. 4 (1): 37. 2017. Doi 10.5430/ijelt.v4n1p37

[29] A. Valentini, J. Ricketts, R. E. Pye, C. Houston-price. Journal of Experimental Child Listening while reading promotes word learning from stories.Journal of Experimental Child Psychology. 67: 10-31. 2018. https://doi.org/10.1016/j.jecp.2017.09.022

[30] A. Wijayanti. Pengembangan Bahan Ajar Teks Cerpen untuk Siswa Kelas VII Sekolah Menengah Pertama (SMP). Nosi. 2 (2): 1-12. 2014.

[31] X. Yang. Cultural Background on Reading Comprehension in Junior High School. Journal of Language Teaching and Research. 8 (2): 370-374. 2017.

[32] Z. Zurqoni, H. Retnawati, E. Apino, R. D. Anazifa. Impact of Character Education Implementation: a Goal-Free Evaluation. Problems of Education in the 21st Century. 76(6): 881-899. 2019. Doi 10.33225/pec/18.76.881

[33] B. Piper, S. S. Zuilkowski, M. Dubeck, E. Jepkemei, S. J. King. Identifying the essential ingredients to literacy and numeracy improvement: Teacher professional development and coaching, student textbooks, and structured teachers' guides. World Development, 106, 324-336. 2018.

[34] T. Surma, K. Vanhoyweghen, G. Camp, P. A. Kirschner. The coverage of distributed practice and retrieval practice in teacher education textbooks. In EARLI SIG 16 Metacognition Conference 2018.

[35] A. K. van den Ham, A. Heinze, Does the textbook matter? Longitudinal effects of textbook choice on primary school students' achievement in mathematics. Studies in Educational Evaluation, 59, 133-140. 2018.

[36] D. Suryaman, K. Hasegawa, S. Kagaya. Combined biological and photocatalytic treatment for the mineralization of phenol in water. Chemosphere, 65(11), 2502-2506. 2006 
[37] H. Sievert, A. K. van den Ham, I. Niedermeyer, A. Heinze. Effects of mathematics textbooks on the development of primary school children's adaptive expertise in arithmetic. Learning and Individual Differences, 74, 101716. 2019.

[38] J. W. Creswell. Research design: Qualitative, quantitative, and mixed methods approaches. America: United States of America. 2014.

[39] A. Prema, H. Okazaki. PREMA: An extensive reading work-in-progress. 2012. 